\title{
Analisis Strategi Pengembangan Usaha Kopi Luwak (Studi Kasus UMKM Careuh Coffee Rancabali-Ciwidey Bandung)
}

\author{
Soni Supriatna \\ Departemen Manajemen, Fakultas Ekonomi dan Manajemen \\ Institut Pertanian Bogor \\ Kampus Darmaga Bogor 16680 \\ Mimin Aminah \\ Departemen Manajemen, Fakultas Ekonomi dan Manajemen \\ Institut Pertanian Bogor \\ Kampus Darmaga Bogor 16680 \\ e-mail:miminaminah@yahoo.com
}

\begin{abstract}
Micro, Small and Medium Enterprises (MSMEs) of Careuh Coffee is a business unit that produces and processes Civet Coffee. Related to the business unit, the objectives of this paper are: 1) to find out the marketing mix that has been applied by MSMEs Careuh Coffee; 2) to identify and analyze both internal and external factors that affect marketing strategies of MSMEs Careuh Coffee; 3) to develope and recommend alternative marketing strategies for MSMEs Careuh Coffee. Internal and external factors that had impacts on development of MSMEs Careuh Coffee are financial condition, human resources, consumer behaviour, information technology and location. This research uses AHP Method. One of the alternative strategies that can be implemented by MSMEs Careuh Coffee is strengthening human resources in marketing. This strategy aims to build a strong foundation in order marketing activities in MSMEs Careuh Coffee to run well. The next strategies are forward integration strategy, optimalization of digital marketing and application of bellow-the-line marketing campaign.

Key words: AHP method, Careuh Coffee, MSMEs, strategies
\end{abstract}

\begin{abstract}
ABSTRAK
UMKM Careuh Coffee merupakan unit usaha yang bergerak di bidang agribisnis yang memproduksi dan mengolah kopi luwak. Terkait dengan unit usaha tersebut, tujuan dari tulisan ini adalah 1) mengetahui bauran pemasaran (marketing mix) yang telah diterapkan oleh UMKM Careuh Coffee; 2) mengidentifikasi dan menganalisis faktor-faktor lingkungan internal dan eksternal yang mempengaruhi strategi UMKM Careuh Coffee; 3) menyusun dan merekomendasikan alternatif strategi yang efektif dan efisien untuk UMKM Careuh Coffee. Faktor-faktor internal dan eksternal yang berpengaruh terhadap perkembangan UMKM Careuh Coffee adalah Kondisi Finansial Perusahaan, Sumber Daya Manusia, Sikap Konsumen, Teknologi Informasi dan Lokasi. Penelitian ini menggunakan metode AHP, hasil alternatif strategi yang dapat dilakukan oleh UMKM Careuh Coffee di antaranya penguatan SDM pemasaran. Strategi ini bertujuan untuk membangun fondasi yang kuat agar UMKM Careuh Coffee berjalan dengan baik. Kemudian strategi selanjutnya berturut-turut adalah startegi integrasi ke depan, optimalisasi digital marketing serta menerapkan promosi bellow-the-line marketing. Kata kunci: Careuh Coffee, strategi, metode AHP, MSMEs
\end{abstract}

\section{Pendahuluan}

Kopi luwak adalah buah kopi hasil fermentasi di dalam perut musang luwak yang dikeluarkan bersama kotoran dalam bentuk biji. Kopi luwak memiliki cita rasa yang 
unik dan kadar keasaman yang rendah, lembut seperti sirup (Marcone 2004; Chan dan Garcia 2011). Kopi luwak berbentuk beras (green bean) berbahan kopi arabika dijual dengan harga Rp 600 000-Rp 1300000 per kg di pasaran (Panggabean 2011a). Selain memiliki potensi ekonomi musang luwak juga berperan dalam penyebar biji di alam (Jotish 2011; Iseborn et al. 2012). Salah satu wilayah penghasil kopi luwak adalah wilayah Kabupaten Bandung. Berbagai merek kopi luwak diproduksi oleh Usaha Mikro, Kecil dan Menengah (UMKM) di Bandung, salah satunya adalah adalah UMKM Careuh Coffee, UMKM ini bergerak dalam bidang agribisnis yang menghasilkan kopi luwak. Kini usaha kopi luwak mulai berkembang, di wilayah Bandung Selatan. Terdapat 3 UMKM yang menghasilkan kopi luwak. Persaingan bisnis menjadikan UMKM Careuh Coffee harus merumuskan serta mengimplementasikan strategi untuk dapat memenangkan pasar. Omset UMKM Careuh Coffee pada tahun 2012-2013 pat dilihat pada Gambar 1.

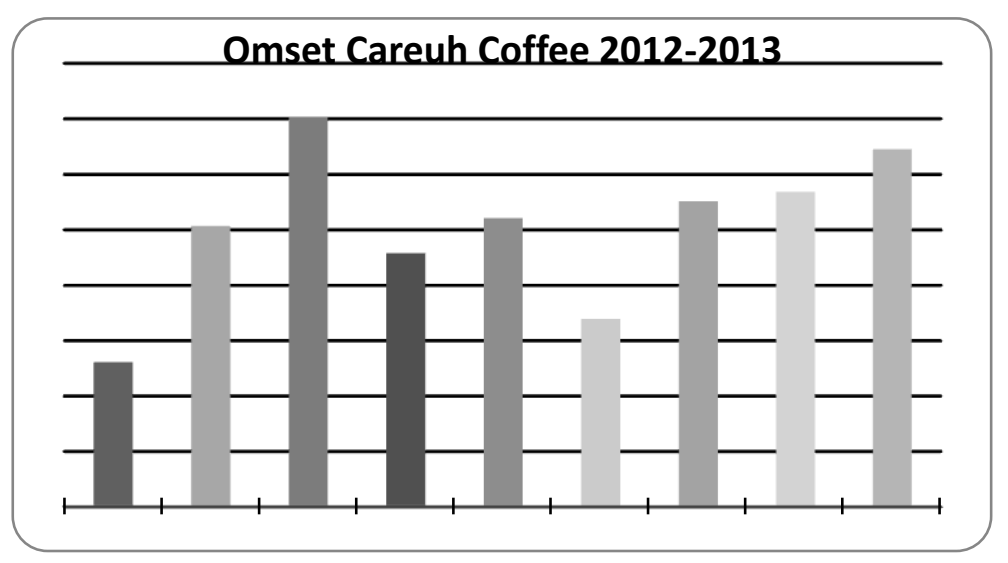

Gambar 1. Omset Careuh Coffee (Careuh Coffee 2013)

Meskipun omset yang saat ini dihasilkan telah menutupi biaya operasional dan telah mendapatkan keuntungan, pihak manajemen menargetakn omset bulanan sebesar 50-100 juta rupiah. Kapasitas produksi yang dihasilkan oleh UMKM Careuh Coffee berkisar antara 50-100 $\mathrm{Kg} /$ bulan, akan tetapi jumlah permintaan rata-rata perbulan hanya berkisar antara 20-30 kg per bulan. Sehingga terjadi kelebihan produksi sekitar $60-70 \mathrm{~kg} / \mathrm{bulan}$. Hal ini menjadi salah satu kendala yang dihadapi oleh UMKM Careuh Coffee. Pihak manajemen berkeinginan untuk memperluas pasar dan membenahi beberapa aspek manajemen agar kedepannya UMKM Careuh Coffee mampu berkembang serta menjadi UMKM yang unggul. Oleh karena itu diperlukan perumusan strategi pemasaran yang sesuai dengan kondisi perusahaan agar UMKM Careuh Coffee dapat lebih berkembang serta tujuan-tujuan perusahaan dapat tercapai. Munculnya pesaing serta lingkungan bisnis yang semakin dinamis membuat sebuah bisnis harus memilki strategi yang tepat agar dapat bersaing serta memenangkan pasar. Berdasarkan latar belakang tersebut, maka permasalahan dapat dirumuskan sebagai berikut: 1) Bagaimanakah gambaran usaha UMKM Careuh Coffe?; 2) Faktorfaktor lingkungan internal dan eksternal apa saja yang berpengaruh terhadap strategi pemasaran UMKM Careuh Coffee?; 3) Bagaimana alternatif strategi pemasaran yang efektif dan efisien untuk UMKM Careuh Coffee?

Merujuk pada rumusan masalah tersebut, tujuan dari penelitian ini adalah: 1) Mendeskripsikan usaha UMKM Careuh Coffe; 2) Mengidentifikasi dan menganalisis 
faktor lingkungan internal dan eksternal yang mempengaruhi strategi pemasaran UMKM Careuh Coffee; 3) Menyusun dan merekomendasikan alternatif strategi pengembangan usaha UMKM Careuh Coffee.

\section{Metode Penelitian}

Penelitian ini dilakukan di lokasi usaha UMKM Careuh Coffe di Jl. Raya CiwideyPatengan No. 151 Km 5 Kecamatan Rancabali Kabupaten Bandung. Pemilihan lokasi dilakukan secara sengaja dengan pertimbangan bahwa Careuh Coffee merupakan UMKM yang berpotensi serta tergolong masih berkembang. Jenis data yang digunakan meliputi data sekunder dan primer. Data primer diperoleh dari pihak internal UMKM Careuh Coffee. Data tersebut meliputi profil usaha, struktur organisasi, segmentation, targeting dan positioning, dan bauran pemasaran Product, Price, Place and Promotion (4P). Sedangkan data sekunder berasal dari literatur-literatur tentang masalah yang akan diteliti, seperti literatur perkembangan UMKM di Jawa Barat, buku mengenai kopi luwak, jurnal strategi pemasaran dan penelitian terdahulu.

Pemilihan responden dilakukan secara sengaja (purposive) dengan pertimbangan bahwa responden tersebut paham mengenai strategi pemasaran UMKM Careuh Coffee. Responden yang dipilih dalam penelitian ini adalah ahli dalam bidangnya, baik yang berasal dari pihak internal maupun eksternal. Responden dalam penelitian ini berjumlah empat orang yaitu pimpinan umum (pendiri sekaligus sekretaris Asosiasi Kopi Luwak Indonesia wilayah Kabupaten Bandung), kepala operasional, manajer pemasaran dan tokoh masyarakat sekaligus pengelelola kawasan wisata Ciwidey.

Langkah pertama dalam merumuskan strategi pemasaran UMKM Careuh Coffee adalah melakukan identifikasi mengenai profil usaha, tujuan serta Visi Misi (Pun dan Hui 2001). Selanjutnya adalah mengidentifikasi faktor-faktor penyusun strategi berdasarkan analisis Segmentation, Targetting and Positioning (STP). Analisis internaleksternal yang bertujuan untuk mendapatkan alternatif strategi pemasaran melalui analisis Strength, Weakness, Opportunity, Threat (SWOT). Selanjutnya, disusun struktur hierarki menggunakan metode Analytical Hierarchy Process (AHP). Struktur hierarki tersebut disusun menjadi kuesioner yang akan dinilai oleh para pakar untuk menentukan strategi pemasaran mana yang tepat untuk UMKM Careuh Coffee. Faktorfaktor penyusun SWOT diperoleh dari teori dan direvisi oleh para responden pakar sesuai dengan usaha yang dijalani.

Metode pengolahan dan analisis data disajikan secara deskriptif dan dianalisis secara kuantitatif serta kualitatif. Analisa kualitatif digunakan untuk mengetahui lingkungan internal, eksternal dan bauran pemasaran serta untuk mendukung analisa kuantitatif yang menggunakan metode AHP. Proses perumusan strategi dilakukan melalui tiga tahap, yaitu tahap masukan (analisis lingkungan internal dan eksternal) tahap pencocokan (Analisis SWOT) dan tahap pengambilan keputusan dengan menggunakan metode AHP (Pun dan Hui 2001).

Analisis Internal dilakukan dengan menganalisis bidang fungsional. Hal tersebut dilakukan untuk mengidentifikasi kekuatan dan kelemahan. Hasil dari analisis tersebut kemudian dituangkan ke dalam bentuk matriks yaitu matriks Internal Factor Evaluation (IFE). Kekuatan dan kelemahan yang telah dianalisis kemudian diberikan bobot. Pembobotan dimulai dari 1 (paling penting) sampai 0 (tidak penting). Selanjutnya 
untuk peringkat setiap faktor dengan angka 4 (baik), 3 (rata-rata), 2 (di bawah ratarata) dan 1 (buruk). Score merupakan hasil perkalian antara vobot dan rating.

Analisis Eksternal bertujuan untuk mengidentifikasi peluang dan ancaman serta untuk melihat kemampuan Careuh Coffee dalam menghadapi perubahan lingkungan eksternalnya. Hasil dari analisis kemudian dituangkan ke dalam bentuk matriks External Factor Evaluation (EFE). Peluang dan ancaman yang telah dianalisis kemudian diberikan bobot melalui metode pairways comparasions, kemudian diberikan rating. Rangkuti (2008) menerangkan bahwa analisis SWOT adalah identifikasi berbagai faktor secara sistematis untuk merumuskan strategi perusahaan. Analisis ini didasarkan pada logika yang dapat memaksimalkan kekuatan (strength) dan peluang (oppurtunity), namun secara bersamaan dapat meminimalkan kelemahan (weakness) dan ancaman (treaths).

Langkah pertama dalam merancang metode AHP yaitu mengidentifikasikan persoalan dengan melakukan analisa yang mendalam terhadap persoalan yang dihadapi dan ingin dipecahkan. Proses selanjutnya adalah pengidentifikasian dan pemilihan elemen-elemen yang akan masuk komponen sistem seperti focus, forces, actors, objectives, dan alternative dalam struktur AHP nantinya. Kemudian membuat struktur hierarki yang diawali dengan tujuan utama. Strukur Hierarki dapat dilihat pada Gambar 2.

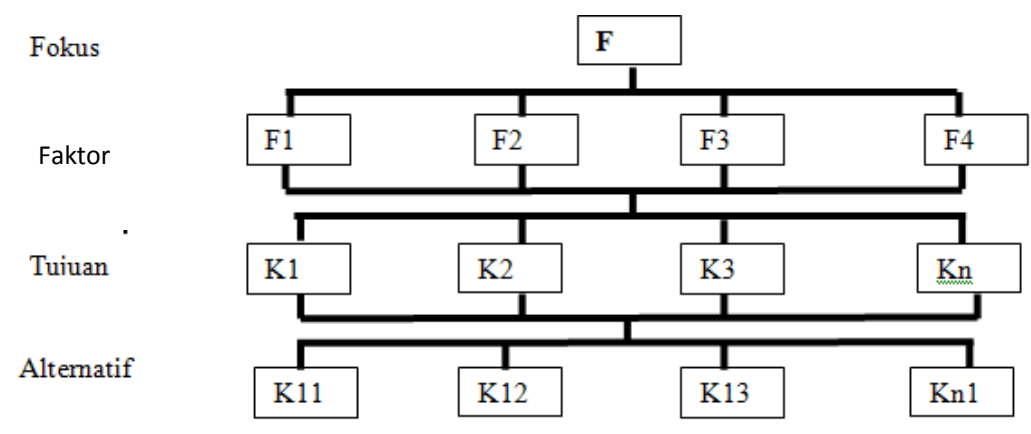

Gambar 2. Struktur hierarki AHP (Marimin 2004)

Hasil pengolahan horizontal menunjukkan elemen-elemen yang berhubungan dalam satu tingkat hierarki dibandingkan dengan elemen-elemen lainnya di tingkat hierarki yang berbeda. Sedangkan hasil pengolahan vertikal menggambarkan keterkaitan dan tingkat pengaruh antara elemen pada satu tingkat hierarki dengan elemen pada tingkat hierarki lainnya. Hasil pengolahan yang menunjukkan pemilihan alternatif strategi pemasaran diperoleh dari pengolahan vertikal.

\section{Hasil dan Pembahasan}

III.1. Sejarah dan Gambaran Umum UMKM Careuh Coffee

UMKM Careuh Coffee merupakan unit usaha di bidang agribisnis yang menyediakan kopi luwak. UMKM Careuh Coffee didirikan oleh Gabungan Kelompok Tani Agro Alam Lestari tahun 2010. Melihat adanya potensi sumber daya lokal di bidang komoditas kopi dan hewan luwak (musang). Pemilik UMKM Careuh Coffe berinisiatif untuk memproduksi kopi luwak serta menangkarkan luwak sendiri. Produk 
yang dihasilkan dengan menangkarkan sendiri akan menghasilkan produk kopi yang unggul, berbeda dengan menggunakan luwak yang hidup bebas, dengan penangkaran luwak sendiri produk yang dihasilkan dapat dijamin tingkat kebersihannya. Saat ini UMKM Careuh Coffee mempunyai satu outlet tetap. Produk yang dihasilkan terdiri dari kopi serbuk kemasan serta produk siap saji dengan berbagai varian rasa. Nama merk yang digunakan adalah UMKM Careuh Coffee. Logo yang digunakan saat ini terdiri dari gambar Luwak serta secangkir kopi panas. Berikut logo dari UMKM Careuh Coffe dapat dilihat pada Gambar 3.

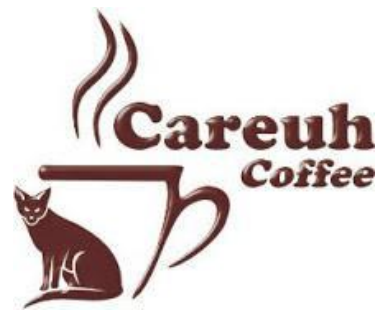

Gambar 3. Logo UMKM Careuh Coffee (Careuh Coffee 2013)

UMKM Careuh Coffee berlokasi di Jl. Raya Ciwidey-Patengan No. 151 Km.5 Kecamatan Rancabali Kabupaten Bandung. Lokasi yang cukup strategis karena merupakan jalur menuju daerah wisata Rancabali-Ciwidey seperti Kawah Putih, Situ Patengan dan lain-lain. UMKM Careuh Coffee tepat berada di dataran tinggi yang mempunyai hawa dingin serta pemandangan kota Bandung dari atas.

Sampai saat ini belum ada visi-misi tertulis, namun dari hasil wawancara dapat disimpulkan bahwa visi utama dari UMKM Careuh Coffee adalah menjadi unit usaha yang terus berkembang serta memberikan manfaat bagi lingkungan sekitar. Misi unit usaha mereka diantaranya menjaga kualitas produk, memberikan pelayanan terbaik kepada pelanggan serta terus mengembangkan pasar.

Sistem kerja pada UMKM Careuh Coffee belum terorganisir dengan baik dan relatif sederhana, banyak job desk yang belum jelas, standar operational procedure (SOP) belum dibuat secara tertulis. Hal ini berdampak negatif pada kelangsungan kegiatan usaha UMKM Careuh Coffee. Saat ini UMKM Careuh Coffee memiliki 7 orang pekerja, sebagian besar berada pada bidang produksi dan beberapa di outlet sebagai pelayan dan kasir, untuk bidang keuangan serta pemasaran dikelola oleh manajer pemasaran dan kepala operasional, dan pimpinan umum pun seringkali ikut langsung dalam operasional. Struktur organisasi dari UMKM Careuh Coffee dapat dilihat pada Gambar 4.

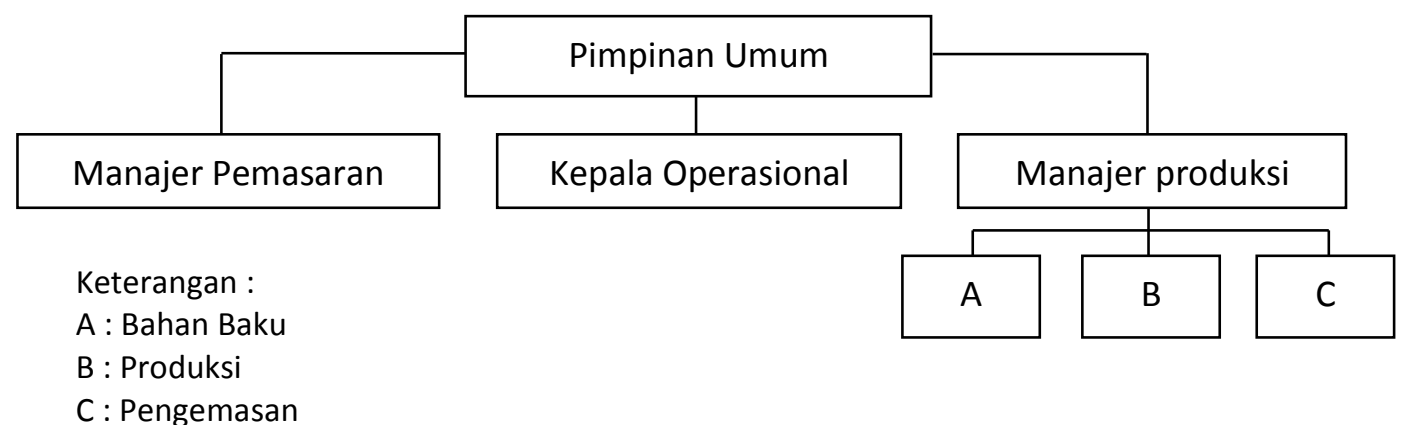

Gambar 4. Struktur organisasi Careuh Coffee (Careuh Coffee 2013) 
Dalam melaksanakan usahanya, aktor yang terlibat secara langsung dalam pengambilan keputusan di antaranya adalah pimpinan umum, kepala operasional, manajer pemasaran dan manajer produksi. Pimpinan umum dari UMKM Careuh Coffee yang sekaligus merupakan pendiri dan pemilik, dan saat ini menjabat sebagai ketua Asosiasi Kopi Luwak Indonesia wilayah Kabupaten Bandung. Pimpinan umum bertanggung jawab terhadap kelangsungan usaha serta mengatur seluruh sistem dan kinerja serta memastikan seluruh kegiatan usaha berjalan dengan baik. Kepala operasional bertanggung jawab terhadap regulasi jalur distribusi kopi luwak dan mengatur pesanan dan penjualan. Manajer pemasaran bertanggung jawab dalam hal aktivitas promosi, membuka pasar baru, menjaga loyalitas pelanggan serta merencanakan rencana-rencana pemasaran. Manajer produksi bertanggung jawab terhadap seluruh kegiatan produksi, mulai dari pemilihan bahan baku, penangkaran luwak, proses produksi hingga produk siap dijual.

\section{III.2. Analisis Lingkungan Internal}

Analisis lingkungan internal digunakan untuk melihat bagaimana kondisi internal dari UMKM Careuh Coffee dengan menggunakan analisis STP dan analisis 4P. Segmentasi berdasarkan demografi yaitu pendapatan serta psikografi yaitu gaya hidup. Target pasar meliputi masyarakat yang menyukai kopi dan menjadikan kopi sebagai salah satu life style mereka. Selain itu target dari UMKM Careuh Coffee adalah wisatawan lokal maupun internasional yang berkunjung ke Ciwidey. UMKM Careuh Coffee memposisikan dirinya sebagai kopi luwak yang mempunyai cita rasa khas dan eksotis.

Kotler dan Amstrong (2006), menyatakan bahwa bauran pemasaran (marketing mix) adalah seperangkat alat pemasaran yang digunakan perusahaan untuk terusmenerus mencapai tujuan pemasarannya di pasar sasaran, alat-alat pemasaran tersebut diklasifikasikan menjadi empat kelompok yang luas yang disebut 4P. Harga produk yang ditawarkan perusahaan lebih tinggi dibanding dengan harga kopi biasa, namun lebih rendah dibanding harga kopi luak pesaing. Produk dan harga kopi berbagai ukuran berat dapat dilihat dalam Tabel 1.

Tabel 1. Harga kopi luwak UMKM Careuh Coffee

\begin{tabular}{clc}
\hline No & \multicolumn{1}{c}{ Ukuran } & Harga (Rp) \\
\hline 1 & Careuh Coffee Serbuk 8g & 15000 \\
2 & Careuh Coffee Serbuk 50g & 70000 \\
3 & Careuh Coffee Serbuk 100g & 130000 \\
4 & Careuh Coffee Serbuk 250g & 320000 \\
5 & Careuh Coffee Serbuk 1kg & 1300000 \\
\hline
\end{tabular}

Sumber: Careuh Coffee 2013

Saat ini UMKM Careuh Coffee telah melakukan beberapa aktivitas promosi. Beberapa aktivitas promosi yang telah dilakukan oleh UMKM Careuh Coffee diantaranya pameran yang difasilitasi oleh pemerintah, digital marketing berupa website dan sosial media, publisitas dari media masa juga pejabat daerah, akan tetapi bentuk promosi belum maksimal dan berkelanjutan. Selain itu promosi juga dilakukan dengan memberi sampel pada pengunjung yang datang ke outlet. 


\section{III.3. Analisis SWOT}

Setelah diketahui STP serta bauran pemasaran dari Careuh Coffee, kemudian dilakukan analisis SWOT untuk melihat kekuatan, kelemahan, ancaman serta peluang.

1. Aspek Kekuatan

a. Produksi dan Penangkaran luwak sendiri

UMKM Careuh Coffee melakukan proses produksi dengan menggunakan musang yang dipelihara sendiri. Kopi luwak difermentasikan menggunakan media luwak (binatang musang), kopi yang sudah siap panen kemudian di berikan kepada luwak untuk dikonsumsi, luwak akan mengkonsumsi kopi tersebut dan akan mengelupaskan kulit dari kopi dan megeluarkan kopi yang telah difermentasi UMKM Careuh Coffee memberikan kopi kepada luwak sebanyak 2 hari sekali. Saat ini UMKM Careuh Coffee mempunyai 23 ekor musang.

b. Nama serta logo yang unik.

Nama dan logo UMKM Careuh Coffee memilki keunikan dari namanya yang menggunakan nama lokal careuh. Careuh berasal dari bahasa sunda yang berarti musang. Kemudian logo yang digunakan berupa gambar karikatur dari musang dengan tambahan gambar sebuah cangkir yang mengesankan kopi panas. Desain yang elegan serta mudah diingat membuat logo serta nama Careuh Coffee menjadi salah satu atribut yang digunakan disetiap kemasan produk dan peralatan yang digunakan. Setelah dilakukan perbandingan dengan kompetitor logo dari UMKM Careuh Coffee lebih variatif (kombinasi tulisan dan gambar).

c. Produk bervariasi

Produk yang dihasilkan adalah Kopi luwak siap saji dengan berbagai variasi seperti Original, Black Coffee, Espresso, Cappucino dan Latte. Selain itu konsumen yang berkunjung ke UMKM Careuh Coffee dapat membawa pulang oleh-oleh berupa Kopi Luwak dalam kemasan serbuk dengan berbagai ukuran (8gr, 50gr, 100gr, 250gr serta $1 \mathrm{~kg}$ ).

d. Lokasi strategis

Ciwidey merupakan salah satu kawasan wisata diwilayah Bandung Selatan yang sudah cukup dikenal luas. Sehingga banyak wisatawan lokal maupun mancanegara yang berkunjung kesana dan beberapa diantaranya berkunjung ke UMKM Careuh Coffee untuk menikmati seduhan kopi luwak. Menurut General Manajer Ekowisata Perum Perhutani Unit III Jawa Barat dan Banten dalam harian Antara, popularitas Wisata Bandung Selatan (salah satunya Ciwidey) dibuktikan dengan jumlah pengunjung wisata yang membludak khususnya pada hari raya tahun 2011 yang mencapai kurang lebih 97000 pengunjung.

2. Aspek Kelemahan

a. Modal yang terbatas

Selama ini pihak UMKM Careuh Coffee dalam memulai maupun menjalankan bisnisnya hanya mengandalkan dana pribadi, sehingga agak sulit untuk mengembangkan bisnis tersebut.

b. SDM yang terbatas

Dari segi kuantitas maupun kualitas, SDM yang saat ini dimiliki masih terbatas. Belum ada tim khusus yang menangani bidang pemasaran (Manajer pemasaran menjalankan tugasnya sendiri dan seringkali dibantu oleh pimpinan umum 
maupun kepala operasional). Selain itu, beberapa personilnya mempunyai pekerjaan atau kesibukan sendiri diluar dari UMKM Careuh Coffe.

c. Pemasaran (promosi) belum intensif

Modal dan SDM yang terbatas memberikan dampak terhadap pemasaran yang saat ini dihadapi oleh UMKM Careuh Coffee. Beberapa aktivtas pemasaran telah dilaksanakan akan tetapi masih belum dilakukan secara optimal. Salah satu contoh yang dapat dikemukakan misalnya ketika UMKM Careuh Coffee berencana melakukan ekspansi ke beberapa Cafe di bandung, dalam implementasinya terkadang tidak ditindak lanjuti dengan benar, walaupun peluang terbuka lebar.

d. Alat produksi pendukung terbatas

Pengolahan kopi luwak akan lebih baik apabila ditunjang dengan alat yang memadai. Modal yang terbatas menjadikan UMKM Careuh Coffee tidak dapat mampu memiliki beberapa alat produksi yang diperlukan, khususnya alat untuk meracik kopi.

3. Aspek Peluang

a. Tren kopi luwak mulai dikenal

Rasanya yang unik dan spesial membuat kopi luwak digemari oleh masyarakat. Hal ini didukung dengan banyaknya media yang memberitakan kopi luwak. Bahkan presiden Republik Indonesia pernah memberikan kopi luwak sebagai oleh-oleh dari Indonesia kepada Perdana Menteri Australia, selain itu acara talkshow Oprah Winfrey pernah membahas mengenai kopi Luwak. Sehingga popularitas dan trend kopi luwak dikalangan masyarakat cukup tinggi hal ini dibuktikan dengan munculnya beberapa usaha kopi luwak.

b. Kopi Luwak memiliki khasiat kesehatan

Penelitian yang dilakukan oleh Massiomo Marcone di Universitas Guelph, Ontario Kanada menunjukan bahwa sekresi endogen pencernaan hewan sejenis musang itu meresap kedalam biji kopi. Sekresi enzim proteolitik memecah kandungan biji protein yang terdapat pada biji kopi, menghasikan peptida dan asam amino bebas menjadi berkurang (Panggabean 2011b). Proses produksi menggunakan musang membuat kandungan protein berkurang sehingga dapat memberikan khasiat kesehatan diantaranya mencegah penyakit saraf, melindungi gigi, menurunkan resiko kanker payudara.

c. Dukungan dari pemerintah

Beberapa bentuk dukungan seperti pemberian pelatihan dan pameran. Selain itu pemerintah Jawa barat pada tahun 2012 mengeluarkan kebijakan Kredit Usaha Rakyat (KUR) yaitu kredit dengan bunga ringan untuk UMKM di wilayah Jawa Barat.

d. Berdirinya Asosiasi Kopi Luwak Indonesia

Tren kopi luwak yang positif membuat banyak pengusaha ramai membuka bisnis kopi luwak, sehingga munculah Asosiasi Kopi Luwak Indonesia sebagai wadah para pengusaha kopi luwak untuk berbagi ilmu, pengalaman juga informasiinformasi terbaru mengenai kopi luwak.

e. Perkembangan Teknologi Informasi 
Menurut data Markplus Insight pada tahun 2012 jumlah pengguna Internet di Indonesia per akhir tahun 2012 mencapai 61,08 juta orang. Angka tersebut naik sekitar $10 \%$ dibandingkan tahun 2011 . Hal ini merupakan peluang yang bisa dimanfaatkan dalam memasarkan produknya melaui media internet, saat ini Careuh Coffee sebenarnya sudah memanfaatkan media online sebagai salah satu tools pemasaranya, akan tetapi UMKM Careuh Coffee belum menggunakan media tersebut secara maskimal.

4. Aspek Ancaman

a. Produk Kompetitor

Bisnis kopi luwak mulai bermunculan, hal ini menjadi salah satu ancaman. Salah satu kompetitior terdekat adalah Cory Pasundan yang berada di wilayah Rawabogo Ciwidey. Berikut perbandingan antara UMKM Careuh Coffee dan Cory pasundan yang dapat dilihat pada Tabel 2. Pada Tabel 2 memperlihatkan bahwa unit usaha Cory pasundan masih dibawah UMKM Careuh Coffee khususnya dari segi kapasitas produksi. Keunggulan dari Cory Pasundan terletak dari sisi pemasaran yaitu adanya pihak ketiga yang memasarkan kopi luwak rutin setiap bulannya, untuk diekspor keberbagai negara, akan tetapi jumlah musang yang dimiliki terbatas sehingga berdampak pada jumlah produksi.

b. Mitos kehalalan yang beredar di masyarakat

Proses fermentasi yang menggunakan binatang luwak membuat munculnya mitos negatif dikalangan masyarakat. Banyak yang menganggap kopi luwak tidak halal dan tidak higienis. Akan tetapi pendapat tersebut adalah salah. MUI telah mengeluarkan fatwa bahwa Kopi Luwak halal untuk dikonsumsi. Careuh Coffee telah tersertifikasi halal oleh LP POMMUI dengan No.0112105616001.

Tabel 2. Perbandingan UMKM Careuh Coffee serta Cory Pasundan

\begin{tabular}{llll}
\hline No & \multicolumn{1}{c}{ Indikator } & \multicolumn{1}{c}{ Careuh Coffee } & \multicolumn{1}{c}{ Cory Pasundan } \\
\hline 1 & Kapasitas produksi & 60-70 kg/bulan & $10 \mathrm{Kg}$ \\
2 & Lokasi & Jalan Alam Endah Bandung & Rawa Bogo \\
3 & Harga & Rp $1300000 / \mathrm{kg}$ & Rp 1000 000/kg \\
4 & Penjualan & Outlet & Pihak ketiga \\
5 & Bahan Baku & Kopi Arabica & Kopi Arabica \\
6 & SDM Pemasaran & Sudah mempunyai & Belum mempunyai SDM pemasaran yang \\
& & & khusus \\
7 & Promosi & Pameran, publisitas & Pameran, publisitas \\
8 & Ternak Musang & 23 Ekor & 4 Ekor \\
\hline Sumber:
\end{tabular}

Sumber: Careuh Coffee (2003) dan hasil pengamatan lapangan (2013)

\section{III.4. Internal Factor Evaluation (IFE) Matrix}

Analisis Internal UMKM Careuh Coffee dilakukan dengan menganalisis bidangbidang fungsional Careuh Coffee. Hal tersebut dilakukan untuk mengidentifikasi kekuatan dan kelemahan. Berikut hasil pembobotan dari matriks IFE, dapat dilihat pada Tabel 3.

Tabel 3. Bobot faktor internal Careuh Coffee

\begin{tabular}{clccc}
\hline No & \multicolumn{1}{c}{ Faktor Internal } & Rataan & Bobot & Skor \\
\hline 1 & Produksi dan penangkaran luwak sendiri & 4 & 0.28 & 1.13 \\
2 & Nama serta logo yang unik & 3.5 & 0.07 & 0.23 \\
\hline
\end{tabular}


Lanjutan Tabel 3.

\begin{tabular}{clccc}
\hline No & \multicolumn{1}{c}{ Faktor Internal } & Rataan & Bobot & Skor \\
\hline 3 & Produk bervariasi & 3.25 & 0.05 & 0.16 \\
4 & Lokasi strategis & 3.25 & 0.09 & 0.29 \\
5 & Modal terbatas & 1.5 & 0.09 & 0.14 \\
6 & SDM terbatas & 1.25 & 0.21 & 0.26 \\
7 & Pemasaran belum intensif & 1.75 & 0.12 & 0.22 \\
8 & Alat produksi pendukung terbatas & 1.5 & 0.08 & 0.13 \\
\hline & Total & & 1 & 2.56 \\
\hline
\end{tabular}

Berdasarkan hasil pembobotan, faktor-faktor internal UMKM Careuh Coffee tertinggi adalah produksi dan penangkaran luwak sendiri (1.13), lokasi strategis (0.25), nama serta logo yang unik (0.23), produk bervariasi (0.16). Sementara untuk aspek kelemahan hasilnya adalah sumber daya manusia (0.26), pemasaran belum intensif (0.22), modal terbatas (0.14) dan terakhir alat produksi pendukung terbatas $(0.13)$.

\section{III.5. External Factor Evaluation (EFE) Matrix}

Analisis Eksternal bertujuan untuk mengidentifikasi peluang dan ancaman serta untuk melihat kemampuan UMKM Careuh Coffee dalam menghadapi perubahan lingkungan eksternalnya yang dianalisis menggunakan Matrix EFE. Berikut hasil pengolahan Matriks EFE, dapat dilihat pada Tabel 4.

Tabel 4. Bobot faktor eksternal Careuh Coffee

\begin{tabular}{clccc}
\hline No & \multicolumn{1}{c}{ Faktor Eksternal } & Rataan & Bobot & Skor \\
\hline 1 & Trend Kopi luwak mulai dikenal luas & 3 & 0.27 & 0.81 \\
2 & Kopi Luwak memiliki khasiat bagi kesehatan & 3.25 & 0.17 & 0.57 \\
3 & Dukungan dari pemerintah & 3 & 0.13 & 0.40 \\
4 & Berdirinya asosiasi kopi luwak & 3.25 & 0.12 & 0.40 \\
5 & Perkembangan Teknologi informasi & 3.75 & 0.16 & 0.59 \\
6 & Produk Kompetitior & 2.5 & 0.07 & 0.17 \\
7 & Mitos negatif kopi luwak dikalangan masyarakat & 2.75 & 0.08 & 0.21 \\
\hline & Total & & 1 & 3.14 \\
\hline
\end{tabular}

Hasil perhitungan menunjukan bahwa nilai tertinggi adalah tren kopi luwak mulai dikenal luas (0.81), perkembangan teknologi informasi (0.59), kopi luwak dipercaya memiliki khasiat bagi kesehatan (0.56), berdirinya asosiasi kopi luwak (0.40), dukungan dari pemerintah (0.40). Sementara untuk ancaman menunjukan bahwa mitos negatif dikalangan masyarakat dengan skor (0.21) dan diikuti produk kompetitor memiliki nilai tertinggi dengan skor (0.17).

\section{III.6. Matriks SWOT}

David (2009) mengemukakan bahwa Integrasi kedepan berkaitan dengan usaha untuk memperoleh kepemilikian atau kendali yang lebih besar atas distributor atau peritel. UMKM Careuh Coffee dapat memperluas pasarnya dengan menjalin kerja sama dengan berbagai tempat wisata, restoran, hotel dan penginapan di wilayah Rancabali-Ciwidey dengan menggunakan sistem konsiyiasi juga melakukan kerjasama dengan berbagai travel agent yang menawarkan paket wisata Ciwidey Bandung, 
sehingga UMKM Careuh Coffee dapat masuk dalam salah satu lokasi atau kunjungan wisatawan yang menggunakan travel agent tersebut serta bentuk kerja sama harus tertulis dan jelas sistem bagi hasilnya.

\begin{tabular}{|c|c|c|}
\hline Eksternal & $\begin{array}{l}\text { Strength } \\
\text { 1. Produksi dan penangkaran luwak } \\
\text { sendiri sehingga menghasilkan } \\
\text { produk yang unggul (S1) } \\
\text { 2. Nama serta logo yang unik dan } \\
\text { khas (S2) } \\
\text { 3. Produk bervariasi (S3) } \\
\text { 4. Lokasi strategis terletak di Jalan } \\
\text { Ciwidey-Rancabali yang } \\
\text { merupakan jalan menuju daerah } \\
\text { wisata (S4) }\end{array}$ & $\begin{array}{ll}\text { Weakness } \\
\text { 1. } & \text { Modal terbatas (W1) } \\
\text { 2. } & \text { SDM Terbatas (W2) } \\
\text { 3. } & \text { Pemasaran belum } \\
& \text { intensif (W3) } \\
\text { 4. } & \text { Alat Produksi } \\
& \begin{array}{l}\text { pendukung terbatas } \\
\text { (W4) }\end{array}\end{array}$ \\
\hline $\begin{array}{l}\text { Opportunity } \\
\text { 1. Trend kopi luwak (O1) mulai } \\
\text { dikenal luas } \\
\text { 2. Kopi Luwak memilki khasiat bagi } \\
\text { kesehatan (O2) } \\
\text { 3. Dukungan dari pemerintah yang } \\
\text { besar untuk UMKM(O3) } \\
\text { 4. Berdirinya Asosiasi Kopi Luwak } \\
\text { Indonesia sebagai wadah } \\
\text { pengusaha kopi luwak (O4) } \\
\text { 5. Perkembangan teknologi } \\
\text { informasi (Internet) (O5) }\end{array}$ & $\begin{array}{l}\text { Strategi SO } \\
\text { 1. Strategi integrasi kedepan } \\
\text { 2. Kolaborasi dengan berbagai } \\
\text { tempat wisata yang ada di daerah } \\
\text { Ciwidey } \\
\text { 3. Optimalisasi kerjasama dengan } \\
\text { berbagai travel agent } \\
\text { 4. Meningkatkan intensitas pameran } \\
\text { (S1) (S2) (S3) (S4) (O1) (O3) (O4 )(O5) }\end{array}$ & \begin{tabular}{|l} 
Strategi WO \\
1. Optimalisasi \\
penerapan strategi \\
Digital Marketing \\
2. Website \\
3. Online Advertisiment \\
4. Social Media \\
(W1) (W2) (O1) (05)
\end{tabular} \\
\hline $\begin{array}{l}\text { Threat } \\
\text { 1. Produk kompetitor (T1) } \\
\text { 2. Mitos negatif tentang Kopi } \\
\text { Luwak (T2) }\end{array}$ & $\begin{array}{l}\text { Strategi ST } \\
\text { 1. Menerapkan promosi below the } \\
\text { line marketing } \\
\text { 2. Spanduk dibeberapa titik } \\
\text { 3. Sticker } \\
\text { 4. Brosur } \\
\text { 5. Event Marketing bekerja sama } \\
\text { dengan tempat wisata } \\
\text { (S1) (S2) (S3) (S4) (T1)(T2) }\end{array}$ & $\begin{array}{l}\text { Strategi WT } \\
\text { 1. Penguatan SDM } \\
\text { pemasaran (W1) } \\
\text { (O1) (O3) }\end{array}$ \\
\hline
\end{tabular}

Gambar 5. Matriks SWOT UMKM Careuh Coffee

Penguatan internal SDM pemasaran, Careuh Coffee dapat dilakukan dengan penguatan SDM khusunya di bidang pemasaran. Beberapa hal yang dapat dilakukan terkait strategi tersebut di antaranya pembagian kerja yang jelas, penjadwalan serta rencana pemasaran jangka pendek maupun panjang yang sistematis dan terstruktur, mengadakan pertemuan rutin yang bersifat santai dengan membahas berbagai hal mengenai UMKM, kendala, tren yang sedang berkembang dan terakhir membuat sistem kompensasi yang jelas. Selain itu, pihak Careuh Coffee dapat menambah personil dalam divisi pemasaran atau merekrut dari internal yang difokuskan untuk bidang pemasaran.

Rekomendasi untuk pihak UMKM Careuh Coffee berdasarkan strategi yang didapat adalah mengoptimalkan penggunaan internet seperti: Website, Social Media Marketing, Online Advertisiment. Strategi below The line Marketing. Bentuk aktivitas BTL yang dapat dilakukan oleh UMKM Careuh Coffee diantaranya pembagian brosur, 
pemasangan spanduk dibeberapa titik menuju outlet UMKM Careuh Coffee serta pembuatan sticker mobil yang diberikan kepada konsumen.

\section{III.7. Analisis Pengambilan Keputusan Strategi Pengembangan}

Berdasarkan hasil Focus Group Discussion dengan para ahli, dari aspek internal dan eksternal dari UMKM Careuh Coffee, terdapat enam faktor utama yang berpengaruh terhadap strategi UMKM Careuh Coffee yaitu kondisi finansial perusahaan, SDM, sikap konsumen, teknologi informasi, produk dan lokasi. Serta aktor yang berpengaruh adalah pimpinan umum, kepala operasional, manajer pemasaran dan manajer produksi. Kemudian tujuan yang ingin dicapai oleh UMKM Careuh Coffee di antarnya adalah meningkatkan omzet perusahaan ekspansi pasar dan meningkatkan loyalitas pelanggan. Terakhir, alternatif strategi yang dapat dipilih berkaitan dengan strategi UMKM Careuh Coffee di antarnya adalah strategi integrasi kedepan, penguatan SDM pemasaran, optimalisasi startegi digital marketing dan penerapan below the line marketing. Berikut struktur hierarki metode AHP UMKM Careuh Coffee, dapat dilihat pada Gambar 6.

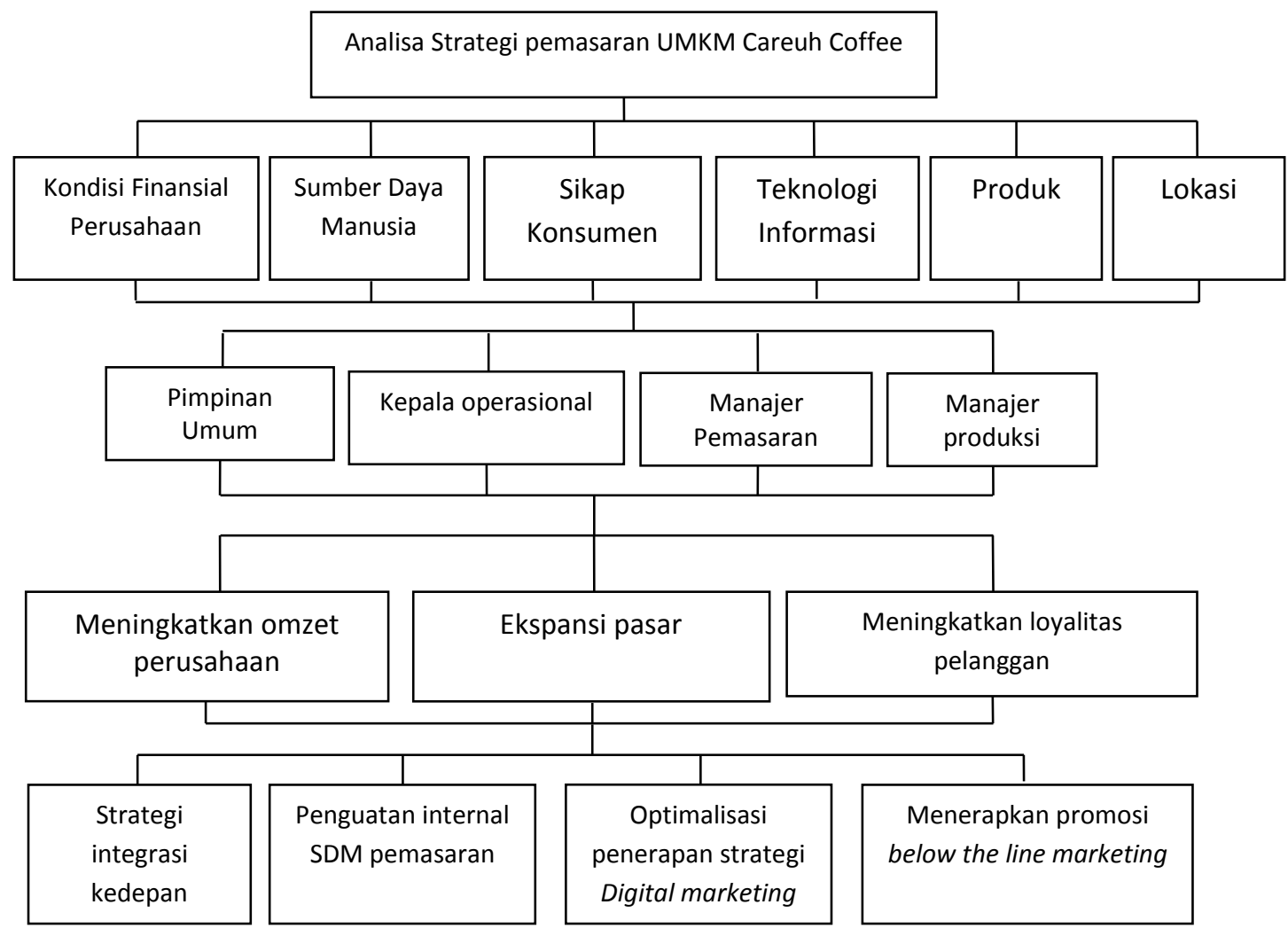

Gambar 6. Struktur hierarki AHP UMKM Careuh Coffee

1. Hasil Pengolahan Horizontal Level Aktor

Pengolahan pada level aktor menunjukan tingkat pengaruh aktor terhadap faktor. Perhitungan level aktor dapat dilihat pada Tabel 5. 
Tabel 5. Perhitungan pada level aktor

\begin{tabular}{lcccccc}
\hline \multicolumn{1}{c}{ Aktor } & \multicolumn{7}{c}{ Faktor } \\
\cline { 2 - 7 } & F1 & F2 & F3 & F4 & F5 & F6 \\
\hline Pimpinan Umum & 0.608 & 0.538 & 0.145 & 0.185 & 0.138 & 0.314 \\
Kepala Operasional & 0.085 & 0.178 & 0.287 & 0.269 & 0.143 & 0.288 \\
Manajer Pemasaran & 0.181 & 0.146 & 0.305 & 0.416 & 0.120 & 0.263 \\
Manajer Produksi Operasi & 0.126 & 0.139 & 0.263 & 0.130 & 0.6 & 0.135 \\
\hline
\end{tabular}

Berdasarkan Tabel 5, Pimpinan Umum (0.608) merupakan aktor yang paling bertanggung jawab terhadap kondisi finansial perusahaan juga bertanggung jawab terhadap kinerja keuangan secara keseluruhan dan berupaya dalam hal pencarian sumber dana. Kemudian pada faktor SDM (F2), Pimpinan Umum (0.538) menjadi aktor yang paling bertanggung jawab terhadap kondisi SDM di UMKM Careuh Coffee. Pada faktor sikap konsumen yang meliputi bagaimana trend serta sikap konsumen terhadap kopi luwak termasuk kopi luwak UMKM Careuh Coffee. Manajer Pemasaran (0.305) merupakan aktor yang paling berpengaruh serta bertanggung jawab terhadap hal ini. Manajer Pemasaran harus responsif terhadap hal-hal yang berkaitan dengan persepsi masyarakat mengenai kopi luwak UMKM Careuh Coffee serta meluruskan berbagai pendapat miring (mitos) mengenai kopi luwak dikalangan masyarakat.

Pada faktor teknologi informasi, Manajer Pemasaran (0.416) menjadi aktor yang paling bertanggung jawab terhadap dalam menyediakan informasi mengenai UMKM Careuh Coffee dengan memanfaatkan teknologi internet, hal ini juga menjadi salah satu aktivitas promosi yang dapat dilakukan UMKM Careuh Coffee untuk mengenalkan produknya ke masyarakat luas. Manajer produksi (0.6) menjadi aktor yang paling bertanggung jawab dalam penyediaan produk kopi Luwak yang berkualitas, yang pada jangka panjang diharapkan untuk terus berinovasi. Kepala operasional (0.314) menjadi aktor yang paling berpengaruh terhadap lokasi apabila dibutuhkan Kepala Operasional harus mencari lokasi baru untuk memperluas penjualan serta tetap mempertahankan lokasi yang saat ini digunakan dengan terus melakukan perbaikan secara berkala mengenai lokasi penjualan saat ini.

2. Hasil Pengolahan Horizontal Level Tujuan

Pengolahan pada level aktor menunjukan tingkat pengaruh aktor terhadap aktorr. Perhitungan level tujuan dapat dilihat pada Tabel 6.

Tabel 6. Pengolahan pada level tujuan

\begin{tabular}{lcccc}
\hline \multicolumn{1}{c}{ Tujuan } & \multicolumn{4}{c}{ Aktor } \\
\cline { 2 - 5 } & PU & KO & MPS & MPO \\
\hline Meningkatkan Omzet Perusahaan & 0.369 & 0.273 & 0.255 & 0.368 \\
Ekspansi Pasar & 0.367 & 0.480 & 0.561 & 0.371 \\
Meningkatkan Loyalitas Pelanggan & 0.264 & 0.247 & 0.184 & 0.260 \\
\hline
\end{tabular}

Berdasarakan Tabel 6, meningkatkan Omzet perusahaan menjadi tujuan utama yang menjadi prioritas Pimpinan Umum (0.369) serta Manajer Produksi (0.368), sementara itu, dalam hal ekspansi pasar, Manajer Pemasaran (0.480) serta Kepala operasional (0.3561) mempunyai prioritas tertinggi. Sementara pada tujuan meningkatkan loyalitas pelanggan, Kepala Operasional serta Manajer Pemasaran mempunyai prioritas tertinggi terhadap tujuan tersebut. Para aktor ini dapat 
melakukan aktivitas pemasaran untuk dapat meningkatkan loyalitas dari para pelanggan UMKM Careuh Coffee.

\section{Hasil Pengolahan Horizontal Level Strategi}

Pengolahan pada level strategi menunjukan tingkat pengaruh strategi terhadap tujuan. Perhitungan level strategi dapat dilihat pada Tabel 7.

Tabel 7. Pengolahan pada level strategi

\begin{tabular}{lccc}
\hline \multicolumn{1}{c}{ Strategi } & \multicolumn{3}{c}{ Tujuan } \\
\cline { 2 - 4 } & T1 & T2 & T3 \\
\hline Strategi Integrasi kedepan & 0.255 & 0.241 & 0.255 \\
Penguatan Internal SDM dan Sistem Pelayanan & 0.519 & 0.391 & 0.386 \\
Optimalisasi Digital Marketing & 0.116 & 0.283 & 0.088 \\
Penerapan Bellow the Line Marketing & 0.131 & 0.085 & 0.271 \\
\hline
\end{tabular}

Meningkatkan omzet perusahaan dapat di capai dengan terlebih dahulu melakukan penguatan Internal SDM pemasaran (0.519). Kemudian diikuti dengan Strategi Integrasi ke depan dengan membuka pasar baru. Sama halnya dengan tujuan pertama, tujuan kedua yaitu meningkatkan ekspansi pasar, strategi yang dapat dilakukan adalah penguatan Internal SDM pemasaran (0.391) diikuti dengan mengoptimalkan penggunaan digital marketing. Tujuan terakhir yaitu meningkatkan loyalitas pelanggan dapat dicapai dengan melakukan strategi penguatan internal SDM pemasaran (0.386) diikuti dengan penerapan strategi below the line marketing. Strategi ini dapat menjangkau konsumen sehingga pada akhirnya akan membuat konsumen loyal dan memberikan efek domino berupa word of mouth terhadap masyarakat luas.

\section{Hasil Pengolahan Vertikal Level Faktor}

Pengolahan pada level Faktor menunjukan tingkat pengaruh faktor terhadap strategi pemasaran UMKM Careuh Coffee. Hasil pengolahan vertikal pada level faktor dapat dilihat pada Tabel 8.

Tabel 8. Hasil perhitungan vertikal pada level faktor

\begin{tabular}{ccc}
\hline Faktor & Bobot & Prioritas \\
\hline F1 & 0.179 & 3 \\
F2 & 0.305 & 2 \\
F3 & 0.058 & 5 \\
F4 & 0.077 & 4 \\
F5 & 0.340 & 1 \\
F6 & 0.041 & 6 \\
\hline
\end{tabular}

Tabel 8 memperlihatkan bahwa faktor yang paling berpengaruh terhadap strategi pemasaran UMKM Careuh Coffee adalah produk (0.340). Produk dari Careuh Coffee yaitu kopi luwak harus tetap dijaga dan ditingakatkan kualitasnya. Faktor yang kedua yang mempengaruhi strategi pemasaran UMKM Careuh Coffee adalah Sumber Daya Manusia (0.305), SDM menjadi hal yang krusial dalam tubuh manajemen UMKM Careuh Coffee, oleh karena itu pihak perusahaan harus kembali membenahi berbagai permasalahan terkait SDM salah satunya SDM yang fokus terhadap pemasaran, hal ini 
dapat dilakukan seperti pembuatan Standard Operating Procedure (SOP) yang jelas dan pertemuan rutin diantara para pimpinan.

5. Hasil Pengolahan Vertikal Level Aktor

Pengolahan pada level aktor menunjukan tingkat pengaruh faktor terhadap strategi pemasaran UMKM Careuh Coffee. Berikut hasil pengolahan vertikal pada level aktor dapat dilihat pada Tabel 9.

Tabel 9. Hasil perhitungan pada Level Aktor

\begin{tabular}{lcc}
\hline \multicolumn{1}{c}{ Aktor } & Bobot & Prioritas \\
\hline Pimpinan Umum & 0.355 & 1 \\
Kepala Operasional & 0.167 & 4 \\
Manajer Pemasaran & 0.178 & 3 \\
Manajer Produksi & 0.299 & 2 \\
\hline
\end{tabular}

Tabel 9 memperlihatkan bahwa Pimpinan umum (0.355) menjadi aktor yang paling bertanggung jawab terhadap strategi pemasaran UMKM Careuh Coffee, Pimpinan umum mempunyai kewenangan dan tanggung jawab dalam berbagai aktivitas usaha UMKM Careuh Coffee. Aktor selanjutnya adalah Manajer Produksi (0.299), Manajer produksi mempunyai kewenangan serta bertanggung jawab dalam menghasilkan produk yang unggul serta berkualitas. Manajer Pemasaran (0.299) menjadi prioritas ke 3 yang mempunyai kewenangan serta tanggung jawab dalam pelaksanaan program-program serta aktivitas pemasaran baik secara online maupun offline. Kepala Operasional (0.178) berada pada prioritas ke 4 yang bertanggung jawab terhadap kegiatan operasional perusahaan serta mendukung aktor lainnya dalam menjalankan masing-masing tugasnya.

6. Hasil Pengolahan Vertikal Level Tujuan

Pengolahan pada level tujuan menunjukan tingkat pengaruh tujuan terhadap strategi pemasaran UMKM Careuh Coffee. Berikut hasil pengolahan vertikal pada level tujuan dapat dilihat pada Tabel 10.

Tabel 10. Bobot dan prioritas tujuan strategi pemasaran UMKM Careuh Coffee

\begin{tabular}{lcc}
\hline \multicolumn{1}{c}{ Tujuan } & Bobot & Prioritas \\
\hline Meningkatkan Omzet perusahaan & 0.332 & 2 \\
Ekspansi Pasar & 0.421 & 1 \\
Meningkatkan loyalitas pelanggan & 0.245 & 3 \\
\hline
\end{tabular}

Tabel 10 menunjukan bahwa tujuan yang ingin dicapai perusahaan adalah ekspansi pasar (0.421), meningkatkan omset perusahaan (0.332), serta meningkatkan loyalitas pelanggan (0.245).

\section{Hasil Pengolahan Vertikal Level Strategi}

Pengolahan pada level strategi menunjukkan tingkat pengaruh strategi terhadap strategi pemasaran UMKM Careuh Coffee. Berikut hasil pengolahan vertikal pada level strategi dapat dilihat pada Tabel 11. 
Tabel 11. Hasil pengolahan vertikal pada level strategi

\begin{tabular}{lll}
\hline \multicolumn{1}{c}{ Strategi } & Bobot & Prioritas \\
\hline Strategi integrasi kedepan & 0.250 & 2 \\
Penguatan SDM serta sistem pelayanan & 0.432 & 1 \\
Optimalisasi Digital Marketing & 0.179 & 3 \\
Menerapkan strategi below the line marketing & 0.139 & 4 \\
\hline
\end{tabular}

Tabel 11 memperlihatkan bahwa strategi yang dapat dilakukan oleh UMKM Careuh Coffee diantarnya penguatan SDM pemasaran (0.402), Strategi integrasi ke depan (0.219), Optimalisasi Digital marketing (0.215) dan Menerapkan strategi below the line Marketing (0.165). Penguatan SDM pemasaran (0.432) menjadi strategi utama yang menjadi prioritas UMKM Careuh Coffee, strategi ini bertujuan untuk membangun pondasi yang kuat agar aktivitas-aktivitas usaha yang ada termasuk strategi pemasaran pada UMKM Careuh Coffee dapat berjalan dengan baik. Strategi selanjutnya adalah strategi integrasi ke depan (0.250). Strategi ini berupa perluasan pasar dalam hal distribusi produk. Strategi berikutnya adalah Optimalisasi Digital Marketing (0.179). Strategi ini untuk memperluas pasarnya serta mempermudah akses masyarakat untuk memperoleh informasi mengenai UMKM Careuh Coffee. Strategi terakhir adalah menerapkan startegi below the line marketing (0.139) berupa aktivitasaktivitas promosi seperti memberikan sticker, brosur, dan pamflet.

\section{III.8. Implikasi Manajerial}

Sumber daya manusia menjadi salah satu hal yang krusial yang dihadapi oleh pihak UMKM Careuh Coffee terutama di bagian pemasaran. Selain itu, sistem manajerial yang belum optimal dan belum terstruktur menjadi kendala yang harus segera dibenahi. Beberapa hal yang dapat dilakukan oleh UMKM Careuh Coffee di antaranya membuat SOP, melakukan pertemuan-pertemuan rutin, pembagian kerja yang jelas dan terstruktur serta sistem kompensasi yang jelas. Kemudian setelah SDM pemasaran terbentuk baik, maka strategi berikutnya dapat dilaksanakan seperti strategi integrasi kedepan, pihak UMKM dapat menjalin kerjasama dengan hotel serta tempat wisata yang berlokasi disekitar kawasan wisata Ciwidey untuk ikut memasarkan produk UMKM Careuh Coffee.

Strategi selanjutnya adalah mengoptimalkan penggunaan strategi Digital Marketing, seperti merenovasi website, optimalisasi penggunaan social media serta membuat sistem atau prosedur yang jelas mengenai bagaimana membeli produk UMKM Careuh Coffee secara online. Pimpinan umum sebagai aktor yang paling berpengaruh terhadap pengambilan keputusan strategi pemasaran UMKM Careuh Coffee, harus mempunyai timeline yang jelas dalam melaksankan strategi-strategi tersebut. Serta mengevaluasi kefektifan strategi yang telah dilaksanakan secara berkala dan memastikan seluruh aktivitas usaha berjalan sesuai rencana. Kemudian strategi yang diimplementasikan harus merujuk terhadap visi-misi serta tujuan utama dari UMKM Careuh Coffee. Produk menjadi faktor paling penting terhadap strategi pemasaran UMKM Careuh Coffee, oleh karena itu pihak UMKM Careuh Coffee harus tetap mempertahankan kualitas Kopi Luwaknya serta terus berinovasi menghasilkan produk kopi luwak yang unggul. 


\section{Kesimpulan}

Bauran pemasaran pada UMKM Careuh Coffee di antarnya adalah produk yang dihasilkan adalah kopi luwak yang berasal dari kopi Arabica. kopi Arabica diambil dari para petani yang berada didaerah Ciwidey Rancabali. Dalam hal tempat, UMKM Careuh Coffee memasarkan produknya melalui Coffee Shop. Harga yang ditawarkan oleh UMKM Careuh Coffee yaitu Rp 1300 000/kg. Dalam hal promosi, UMKM Careuh Coffee telah melakukan aktivitas-aktivitas promosi di antaranya pameran, brosur, dan publisitas. Faktor-faktor internal dan eksternal yang berpengaruh terhadap perkembangan UMKM Careuh Coffee adalah kondisi finansial perusahaan, sumber daya manusia, sikap konsumen, ieknologi Informasi dan lokasi. Alternatif strategi pemasaran yang dapat dilakukan oleh UMKM Careuh Coffee di antaranya penguatan SDM pemasaran dan startegi integrasi ke depan .

\section{Daftar Pustaka}

Careuh Coffee. 2013. [internet].[diunduh pada November 2014]. Tersedia dari: http://www.indonetwork.co.id/careuhcoffee/profile

Chan S, Garcia E. 2011. Comparative Physiochemical Analyses of Regular and Civet Coffe. The Manila Journal of Science, 7(1): 19-23

David FR. 2009. Manajemen Strategis Konsep. Edisi 12. Jakarta (ID): Penerbit Salemba Empat

Iseborn T, Rogers LD, Rawson B, Nekaris KAl. 2012. Sightings of common palm civets (Paradoxurus hermaphroditus) and of other civet species at Phnom Samkos Wildlife Sanctuaryand Veun Sai-Siem Pang Conservation Area, Cambodia. Small Carnivore Conservation, (46): 26-29.

Jotish PS. 2011. Diet of the common palm civet Paradoxurus hermaphroditusin a rural habitat in Kerala, India, and its possible role in seed dispersal. Small Carnivore Conservation, (45): 14-17.

Kotler P, Armstrong G. 2008. Prinsip-prinsip Pemasaran (Terjemahan). Jakarta (ID): Penerbit Erlangga.

Marimin. 2004. Teknik dan Aplikasi Pengambilan Keputusan Kriteria Majemuk. Jakarta (ID): Grasindo.

Marcone MF. 2004. The science behind luwak coffee: An analysis of the world's rarest and most expensive coffee. Annals of Improbable Research (1).

Panggabean E. 2011a. Mengeruk untung dari bisnis kopi luwak. Jakarta (ID): Agromedia Pustaka

Panggabean E. 2011b. Buku Pintar Kopi. Jakarta (ID): Agromedia Pustaka

Pun KF, Hui IK. 2001. An analytical hierarchy process assessment of the ISO 14001 environmental management system. Integrated Manufacturing Systems, 12, 5; ABI/INFORM Complete Pg. 333.

Rangkuti F. 2008. Analisis SWOT Teknik Membelah Kasus Bisnis. Jakarta (ID): PT Gramedia Pustaka Utama. 